Available online on 15.12.2019 at http://jddtonline.info
Open Access to Pharmaceutical and Medical Research
unrestricted non-commercial use, provided the original work is properly cited

Open Access

Case Study

\title{
Non-Healing Ulcer, managed through Unani Formulation along with Leech Therapy: A Case Study
}

\author{
Minhaj Ahmad $^{1 *}$, Zehra Zaidi² ${ }^{2}$ Abdul Nasir ${ }^{2}$
}

1. *Associate Professor \& Head, Department of Jarahiyat (Surgery), School of Unani Medical Education \& Research, Jamia Hamdard (Deemed to be University), New Delhi, India. email: dranasirm@gmail.com

2. Assistant Professor, Department of Ain, Uzn, Anaf wa Halaq (Eye \& ENT ) School of Unani Medical Education \& Research, Jamia Hamdard (Deemed to be University), New Delhi, India.

\begin{abstract}
A male patient aged 43yrs. came to surgery OPD Majeedia Unani Hospital Jamia Hamdard New Delhi, in September 2018 with the complain of ulcer in the right foot posteriorly along the necrosis of Tendon Achilles. He was unable to walk a distance of about 100 meter due severe pain in the ulcer and calf muscle. limping on movement was very prominent. After required investigations and local examination of wou nds, patient was planned and treated by local application, and combination of Unani Medicines formulations along with leech therapy as described in texts of Unani System of Medicine. With this Unani treatment non healing ulcer completely healed without any locomotor disturbances. The condition of leg totally resolved without any complications and side effects.
\end{abstract}

Keywords: Non healing ulcer, Unani medicine, leech therapy.

Article Info: Received 04 Oct 2019; Review Completed 19 Nov 2019; $\quad$ Accepted 28 Nov 2019; Available online 15 Dec 2019

\section{Cite this article as:}

Ahmad M, Zaidi Z, Nasir A, Non-Healing Ulcer, managed through Unani Formulation along with Leech Therapy: A Case Study, Journal of Drug Delivery and Therapeutics. 2019; 9(6-s):211-215 http://dx.doi.org/10.22270/jddt.v9i6-s.3750

*Address for Correspondence:

Minhaj Ahmad, Associate Professor \& Head, Department of Jarahiyat (Surgery), School of Unani Medical Education \& Research, Jamia Hamdard (Deemed to be University), New Delhi, India.

\section{INTRODUCTION}

The incidence of non-healing ulcer is 1-2 percent in developed countries.In Indian community its prevalence reported in year 2004 was 4.8 per 1000 populations. It may increase many fold in future because of increase in number of old person, diabetes mellitus and vascular diseases. ${ }^{1}$

Chronic non-healing ulcer are ulcer that have failed to progress through a timely sequence of repair, or one that proceeds through the wound healing process without restoring anatomic and functional results. Typically, there is a physiological impairment that slows or prevents healing of an ulcer. ${ }^{2}$

Although there is no clear consensus in the duration of anulcerwhich do not heal within 6 weeks to 3 months. The Wound Healing Society classifies chronic non-healing ulcer into 4 major categories: pressure ulcers, diabetic foot ulcers, venous ulcers, and arterial insufficiency ulcers. When ulcer healing is impaired, there is usually not a single factor, but rather multiple contributing factors on work. This is due to the fact that there are overlapping mechanisms in normal ulcer healing that prevent a single factor from disrupting the process. However, when the ulcer healing process is disrupted and ulcer healing is impaired, chronic non-healing ulcers will develop. In general, non-healing ulcers share similar characteristics: high level of proteases, elevated inflammatory markers, low growth factor activity, and reduced cellular proliferation. There are several factors that affect ulcer healing and contribute to the pathogenesis of chronic ulcers. Some of the common factors are infection, ischemia, metabolic conditions, immunosuppression, and radiation.2,3,4 It is advocated that removal of crust and dead necrosed tissue from the floor enhance the process of granulation and healing. keeping the mechanism in mind the initiatives were taken for the treatment of non-healing wound. Oral \& local medication and debridement by any method (manual or enzymatic) is basic principle of treatment. Enzymatic debridement involves application of commercially available enzymatic agents such as collagenase or papain to the wound. Collagenase is an enzyme isolated from the bacterium Clostridium histolyticum. It possesses the ability to selectively digest collagen in necrotic tissue but not in healthy tissue. Papain is a proteolytic enzyme that is found naturally in the papaya fruit. Its proteolytic function must be activated by urea which is also included in the commercially 
available papain formulation. Another papain ointment formulation contains papain, urea and chlorophyllin. Similar to collagenase, papain selectively digests proteins in nonviable tissue and spares the healthy granulation tissue. It is the general consensus that enzymatic debridement and autolytic debridement are slow and are only effective in wounds with minimal necrosis. They can be used as an adjunct to surgical debridement.5,6

Leeches are very effective in the treatment of non-healing ulcer and recommended by ancient physicians for the treatment.

Medicinal leech therapy or hirudo therapy is a kind of complementary and integrative treatment method applied with blood-sucking leeches. One or more leeches are attached to the skin of problematic area and the purpose is to gain potential utilities of leech saliva that is secreted while the leeches are feeding.Medicinal leech therapy has been used for centuries and the term leech was provided from the word "laece" (physician). The first recorded applications were observed in ancient Egypt.7

\section{A CASE STUDY}

A male patient aged 43yrs. came to surgery OPD Majeedia UnaniHospital Jamia Hamdard New Delhi, in September 2018 with the complain of ulcer in the right foot. According to the Patient, he got trauma in right footposteriorly, 23years ago, and operated for Tendon Achilles Lengthening Surgery on posterior aspect of ankle Right Foot, after that he was quite well. Six months ago he gradually noticed pus discharge from the stitch line on posterior aspect of ankle of right foot with pain and difficulty in walking. Pus was watery with no foul smell. The pain was mild, continuous, nonradiating, localized and throbbing in nature. Pain aggravated while walking. Patient took medicines but not relieved. Gradually it turned into a big non-healing ulcer. Initially the ulcer was small in size but gradually it increased longitudinally in size $7.5 \mathrm{~cm} \times 2.0 \mathrm{~cm} \times 1.2 \mathrm{~cm}$ and it was single in number. The edge of the ulcer was glossy, oedematous, inflamed, induration in surrounding area withunhealthy, damaged and partially broken Tendon Achilles in the floor.

By occupation the patient is security guard in a building, mostly in standing position. He was heavy smoker (30 bidi/day).

In general examination; general condition was good, no pallor, icterus, cyanosis, and clubbing was noted. Vitals within normal limit, no abnormality was detected in respiratory and cardiovascular system, gastrointestinal, urinary system and nervous system.

\section{INVESTIGATION}

1.CBC- Hb-15.2 gm\%, ESR- $14 \mathrm{~mm} / \mathrm{hr}$
2.Blood Sugar -Fasting-110mg/dl, Post-prandial-140mg/dl, HbA1c- 6.3

3.LFT-S. Bilirubin Total- 0.8mg/dl, S. Bilirubin Direct$0.5 \mathrm{mg} / \mathrm{dl}, \mathrm{S}$. Bilirubin Indirect-0.3mg/dl,SGOT- $50 \mathrm{IU} / \mathrm{L}$, SGPT- 56 IU/L, S. Alkaline Phosphatase-110 IU/L

4.KFT-Blood Urea- $27 \mathrm{mg} / \mathrm{dl}$, S. Creatinine- $1 \mathrm{mg} / \mathrm{dl}$, S. Uric Acid- $5.6 \mathrm{mg} / \mathrm{dl}$,S. Protein Total- $6.9 \mathrm{mg} / \mathrm{dl}$, Albumin- $3.8 \mathrm{~g} / \mathrm{dl}$, Globulin- 3.1g/dl

5.Biopsy (tissue from the posterior aspect of ankle). No Significant histological changes seen in the section study

6.Pus Culture- only a few commensal (diptheroid) growthPus Sensitivity-Mainly fibrinous material, -A few pus cells, A few diptheroid seen

\section{HbsAg- Non Reactive}

8.HIV- Non Reactive

9.Bleeding Time- $1 \mathrm{~min} 30 \mathrm{sec}$

10.Clotting Time-6min $50 \mathrm{sec}$

11.X-Ray foot- Diffuse osteopenia is seen. Small calcaneal spur is seen. Degenerative changes in ankle joint.

\section{TREATMENT METHOD (Unani Medicines)}

\section{Oral Medication}

- MajonUshba 10gm Morning

- QursMusaffi2 twice a day

- ArqShahtra $125 \mathrm{ml}$. twice a day

- Q. Asfer 2 twice a day

\section{Local Treatment}

- Cleaning of the wound by neem water/normal saline. ${ }^{8}$

- Application of honey on the floor of ulcer.

- A secondary unripe meshed papaya dressing was then placed over the wound compression wrap was then applied.

- $\quad$ Leeching twice a week (2-3 leeches).

- Papaya and honey along with the debridement of the tissue is done in OT. Majeedia Unani Hospital.

- Patient educated about ulcer care and prevention.

- He was encouraged to lose weight, stop smoking, and elevate his leg when possible.

- $\quad$ During the first week the dressing had to be changed daily due to the copious amount of drainage from the wound 
Table-1: Gradation criteria for assessment of ulcer

\begin{tabular}{|c|c|c|c|c|}
\hline \multirow{2}{*}{$\begin{array}{l}\text { Parameters for } \\
\text { Assessment }\end{array}$} & \multicolumn{4}{|c|}{ Gradation criteria } \\
\hline & 0 & + & ++ & +++ \\
\hline Size & $\begin{array}{l}\text { No discontinuity of } \\
\text { skin/mucus membrane }\end{array}$ & $\begin{array}{l}1 / 4 \text { of previous area of } \\
\text { the ulcer }\end{array}$ & $\begin{array}{l}1 / 2 \text { of previous area of the } \\
\text { ulcer }\end{array}$ & $\begin{array}{l}>1 / 2 \text { of previous area of the } \\
\text { ulcer }\end{array}$ \\
\hline Pain & No pain & $\begin{array}{l}\text { Localized pain during } \\
\text { movement but } \\
\text { relieved on rest }\end{array}$ & $\begin{array}{l}\text { Localized pain even during } \\
\text { rest }\end{array}$ & $\begin{array}{l}\text { Localized pain even during } \\
\text { rest and also towards other } \\
\text { side }\end{array}$ \\
\hline Discharge & $\begin{array}{l}\text { No discharge/Dry } \\
\text { dressing }\end{array}$ & $\begin{array}{l}\text { Scanty, occasional } \\
\text { discharge/ Little wet } \\
\text { dressing }\end{array}$ & $\begin{array}{l}\text { Often discharge needs } \\
\text { daily dressing }\end{array}$ & $\begin{array}{l}\text { Profuse, continuous } \\
\text { discharge needs frequent } \\
\text { dressing }\end{array}$ \\
\hline Smell & No smell & Bad smell & $\begin{array}{l}\text { Tolerable, unpleasant } \\
\text { smell }\end{array}$ & Foul and intolerable smell \\
\hline Edge & Adhere edge & $\begin{array}{l}\text { Smooth, even and } \\
\text { regular edge }\end{array}$ & Rough, irregular edge & Angry look \\
\hline Floor & $\begin{array}{l}\text { Smooth, regular with } \\
\text { granulation tissue/ No } \\
\text { need for dressing }\end{array}$ & $\begin{array}{l}\text { Rough, regular, mild } \\
\text { discharge, less } \\
\text { granulation } \\
\text { tissue/needs dressing }\end{array}$ & $\begin{array}{l}\text { Unhealthy, less } \\
\text { granulation tissue/ needs } \\
\text { daily dressing }\end{array}$ & $\begin{array}{l}\text { Unhealthy, no granulation } \\
\text { tissue }\end{array}$ \\
\hline
\end{tabular}

Table-2: Observation of prognosis of ulcer as per assessment criteria

\begin{tabular}{|l|c|c|c|c|c|}
\hline \multirow{2}{*}{$\begin{array}{l}\text { Sign } \\
\text { Symptoms }\end{array}$} & and & Before Treatment & \multicolumn{2}{l|}{ After treatment } & \\
\cline { 2 - 6 } & Day1 & 1 weeks & 2 weeks & 3 weeks & 4 weeks \\
\hline Size & +++ & +++ & ++ & ++ & - \\
\hline Pain & ++ & ++ & + & + & - \\
\hline Edge & ++ & ++ & + & + & - \\
\hline Floor & ++ & ++ & + & - & - \\
\hline Discharge & ++ & + & - & - & - \\
\hline Smell & ++ & & & - \\
\hline
\end{tabular}

\section{RESULT}

The overall treatment process as it relates to wound size is summarized in Figure 1. Within one week the drainage had decreased significantly, the wound appeared unhealthy, raw and red and the wound edges were dry and callous. Pain remained mild.
The wound measured $7.5 \mathrm{~cm} \times 2 \mathrm{~cm} \times 1.2 \mathrm{~cm}$. Pain was at a tolerable level (4-5 on pain scale) with only occasional analgesia. By the end of $1^{\text {st }}$ week the ulcer was $6.5 \mathrm{~cm} \times 1.0$ $\mathrm{cmx} 1.0 \mathrm{~cm}$ with dead tissue and tendon Achilles present on the floor ulcer. The surrounding area was edematous, dark pigmented and firm to palpate.

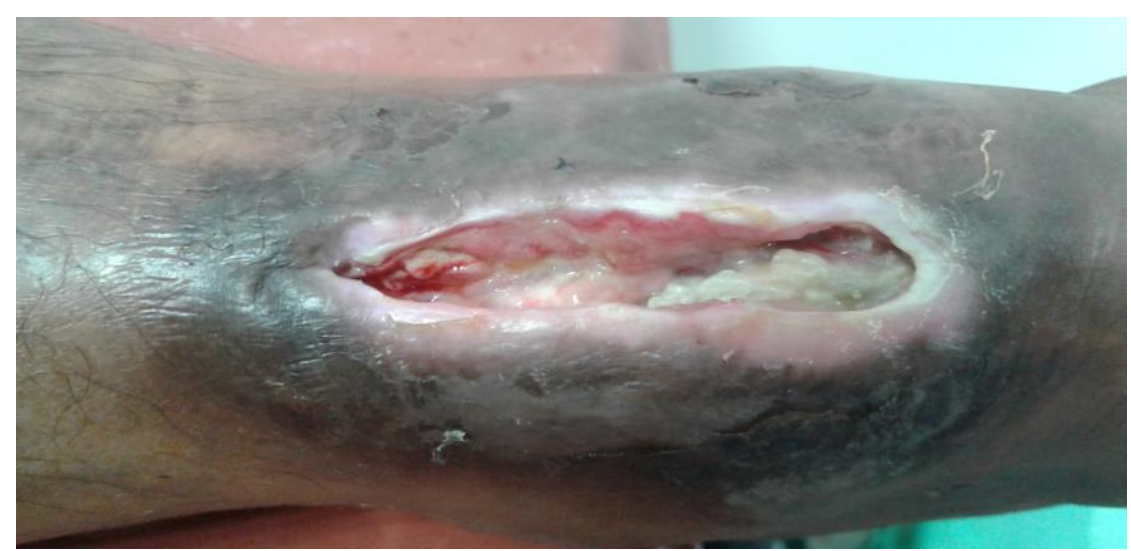

Fig. 1 After 2 days of admission 


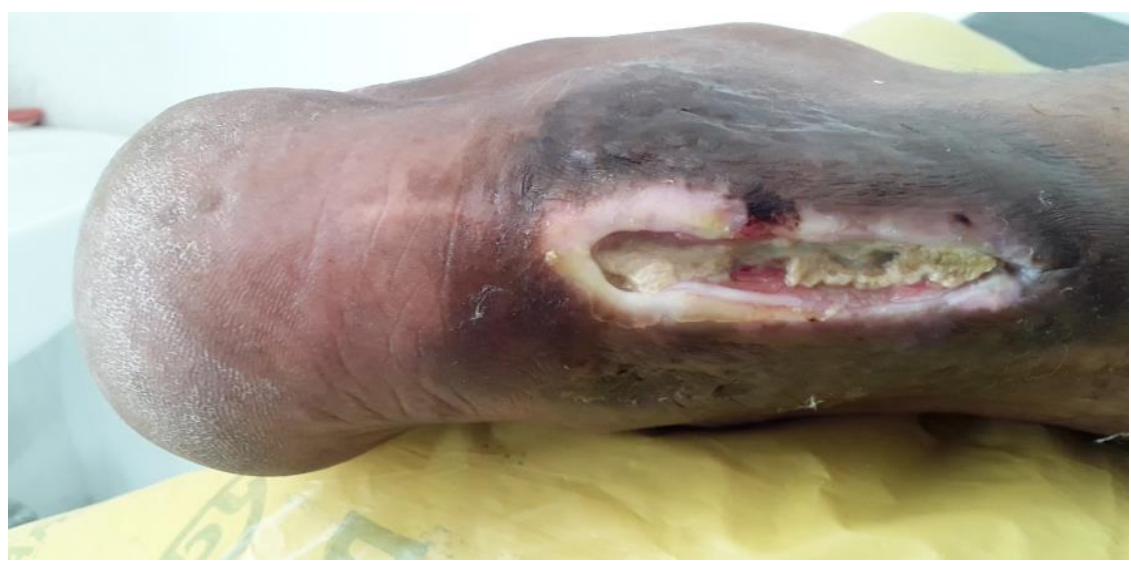

Fig. 2 After 1 weeks showing dead tendon Achilles

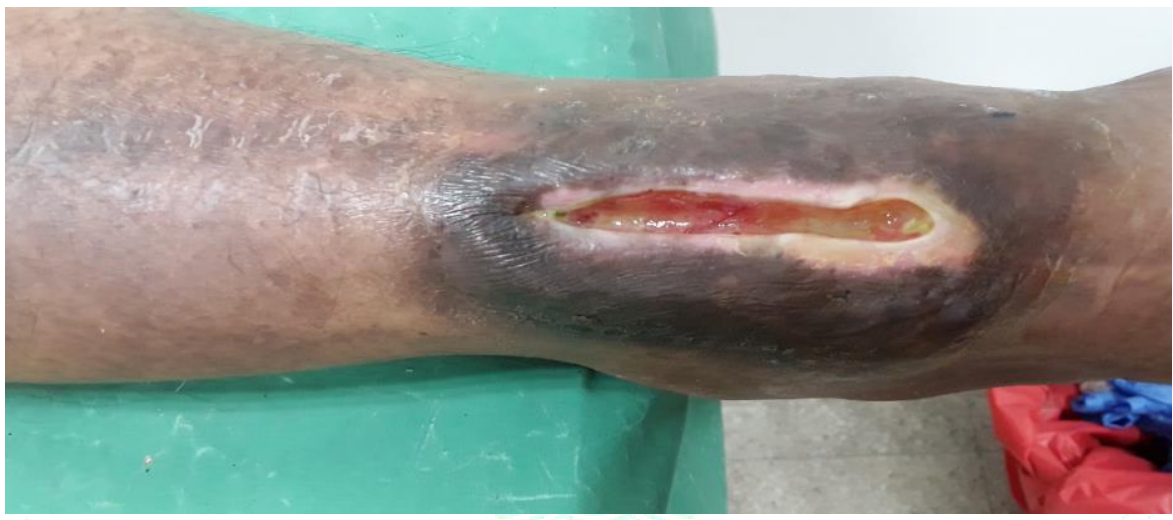

Fig.3 Dead Tendon Achilles, removed

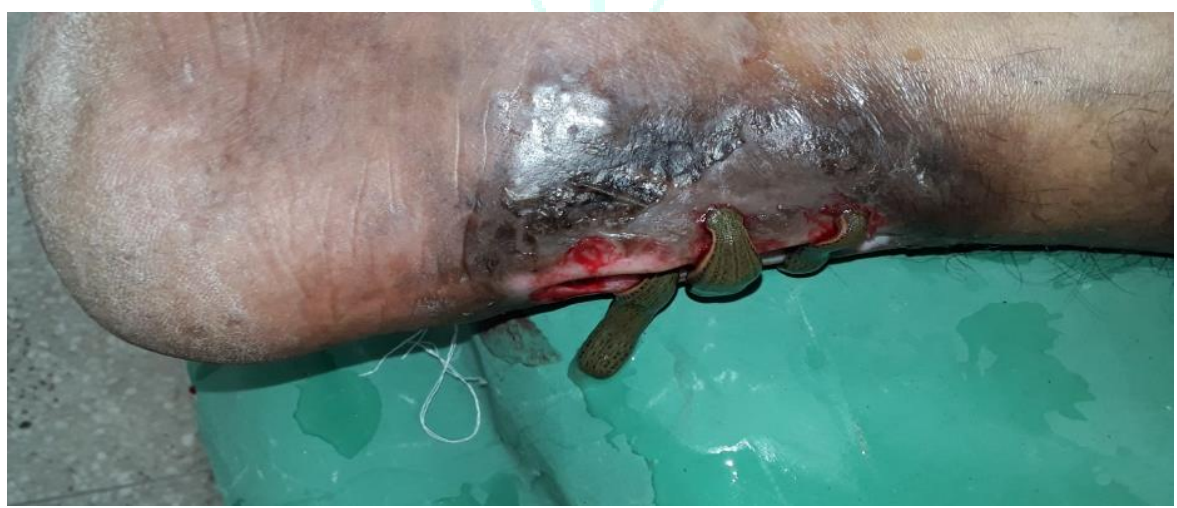

Fig. 4 Leech application on wound $2^{\text {nd }}$ week

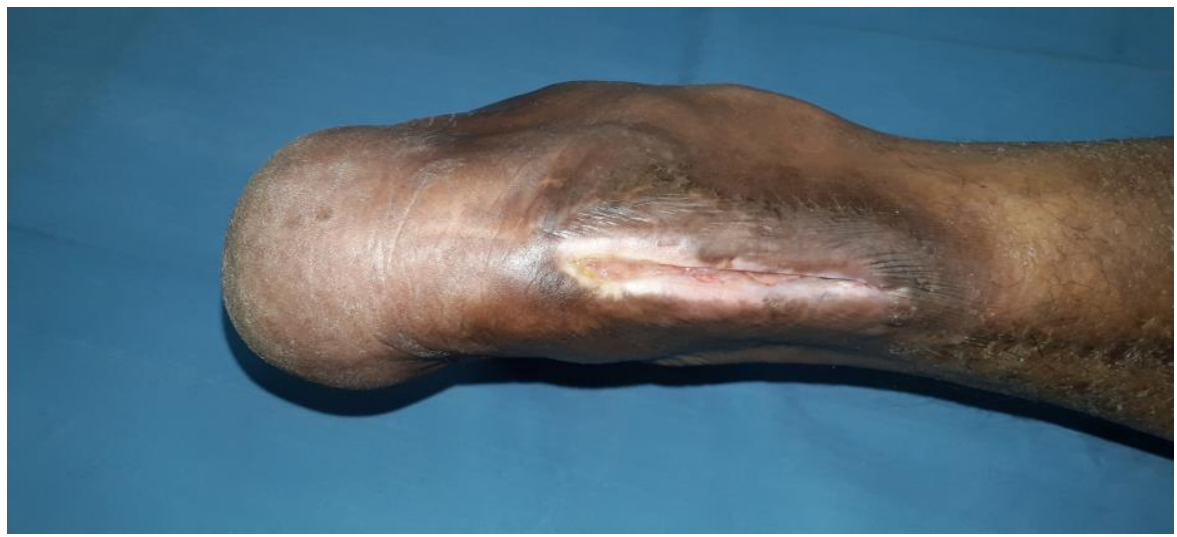

Fig. 5 After 4 weeks' ulcer $98 \%$ healed 


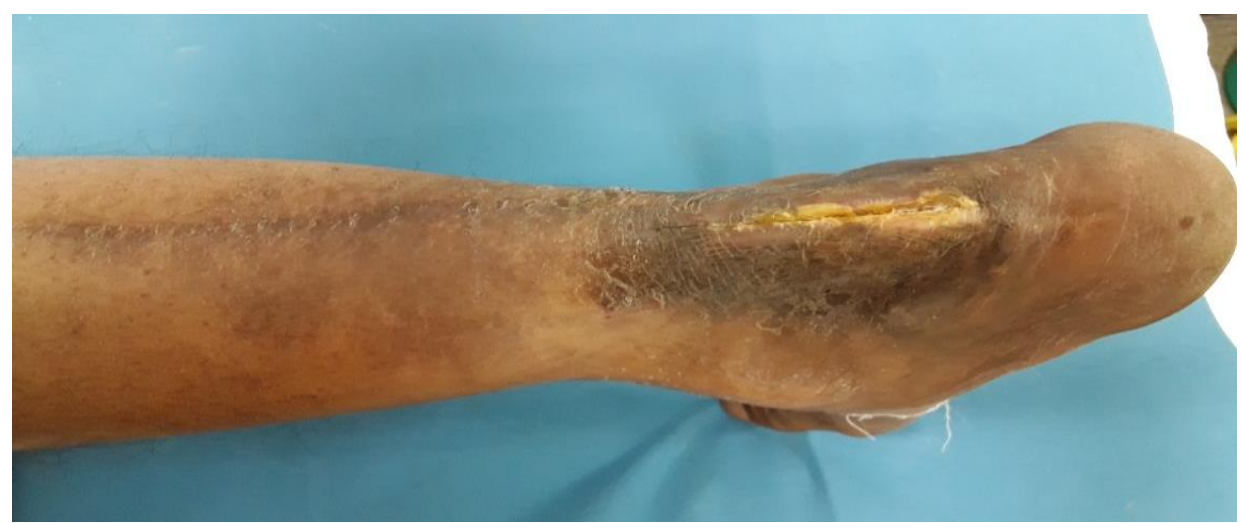

Fig. 6 Wound healed completely

The meshed unripe papaya dressings were used off and on for approximately 4 weeks to completely heal the wounds. Initially the dressings were changed on a daily basis because of the copious amounts of drainage.

The dressings were changed on average every day. The wound floor, surrounded by sloughing necrotic tissue, gradually changed to a healthy pink granulating wound. The patient complained for increased pain when the dressing was removed and also when the wound came into contact with the air.

Once the treatment was completed and the wound was healed the pain decreased significantly.

The wound healed completely, after taking 4-month treatment.

\section{CONCLUSION}

$>$ Based on the results of this case study, it was concluded that meshed unripe papaya dressing was beneficial for a non-healing chronic ulcer. Papaya does not only remove the dead and devitalized tissue, but also ensure the growth of healthy granulation tissue.

$>$ Antimicrobial Barrier Dressing was a good dressing of choice. The ulcer was continuing to regress until the unripe papaya dressing treatment was initiated. The dressing may have created an environment that may have helped decrease the bacterial burden of the wound, which can often be the cause of delay healing of wound.

$>$ It also resulted in less frequent dressing changes, which decreased the cost to our health care system.
The dressing is a simple treatment modality. Thus it is suggested that the study should be done on a large sample size to validate the efficacy of drugs.

\section{REFERENCES}

1. Jarbrink K, Ni G, Sonnergren H, Schmidtchen A, Pang C, Bajpai $\mathrm{R}, \mathrm{Car} J$ : Prevalence and incidence of chronic wounds and related complications: a protocol for a systematic review. Syst Rev 2016, 5(1):152.

2. Shenoy K Rajgopal, Manipal Mannual of Surgery, 2nd edition, CBS Publishers, New Delhi, 2009.p.90-98.

3. Das S, A Concise Textbook of Surgery, 3rd edition, published by Dr. S Das 13, Old Mayor's Court, Calcutta; 1992.p.30-38.

4. Bailey \& Love"s, Short Practice of Surgery, edited by RCG Russell, N.S. Williams, CJK Bulstrode, 26th edition, International Students Edition, published by CRC Press, Tylor \& Francis group, 2013.p.52.

5. Health Quality 0: Management of chronic pressure ulcers: an evidence-based analysis. Ontario Health Technology Assessment Series 2009, 9(3):1-203.

6. Vasuki V Et al. Comparative study of papaya dressing versus normal saline dressing in healing of ulcers, International Surgery Journal, 2017 Apr.; 4(4): 1209-1216.

7. Tettamanti G \& Grimaldi A, et.al, the multifunctional role of fibroblasts during wound healing in Hirudo medicinalis (Annelida, Hirudinea) Biology of the Cell, 2004; 96(6): 443455 .

8. Biswas K, Chattopadhyay I, Banerjee RK, Bandyopadhyay U, Biological activities and medicinal properties of neem (Azadirachta indica) 